\title{
THE ACCOUNTING STANDARDS AND FINANCIAL REPORTING IN ALBANIA Rezarta Shkurti ${ }^{1}$, Brunilda Duraj ${ }^{2}$
}

\begin{abstract}
Albania implemented its first set of 14 National Accounting Standards (NAS), which were prepared in compliance with the International Financial Reporting Standards, in 2009. The 15th standard, specifically the Accounting Standard for financial reporting by micro-entities, was added to this set in 2011 and a 16th standard, relating to the reporting for non-profit enterprises, was added in 2015. In 2014, the National Accounting Council of Albania (NACA) performed a major revision of this existing framework of NAS. The focus of this paper is to analyze the current status, as well as the development of accounting and financial reporting in Albania for the Small and Medium Enterprises (SMEs). An international standard of financial reporting for SMEs was issued by the International Accounting Standards Board but was not fully endorsed by the European Community, nor by the NACA, who instead chose to revise their current NAS. In this study, we provide a general overview of the accounting regime and platforms currently applied in Albania, by focusing on the changes over the recent years. We also depict the main differences between the IFRS for SMEs and the NAS in Albania in treatment of several elements of the financial statements.
\end{abstract}

JEL Classification Numbers: M41, DOI: http://dx.doi.org/10.12955/cbup.v4.748

Keywords: accounting standards, financial reporting, SME.

\section{Introduction}

Varying definitions of the Small and Medium Enterprises (SMEs) exist because of differing characteristics and global differences between regions. Darren L, \& Conrad, L in their study published in 2009 present several definitions of small and medium entities. Arowomole (2000) argues that it is not easy to arrive at a single globally accepted definition of a SME, as different countries apply different criteria, such as management structure, labor force, and total amount of investments to categorize these entities.

According to Arowomole, another factor contributing to the high variety of SME definitions relates to variations given in the research and studies of experts. Nevertheless, despite all the differences reported in literature, there is at least one usual similarity among the SME classifications; namely, the SME entities have three categories: micro-enterprises, small business, and medium economic entities.

In Albania, the earliest categorization of SMEs occurred in 2002, when Law No. 8957, "On Small and Medium Enterprises", classified SMEs as those enterprises that employed from 5 to 80 employees and that realize an annual turnover not exceeding 80 million Albanian lek (ALL; approximately 570,000 Euro). Economic entities with 1-4 employees were considered micro-enterprises. However, the Albanian economy evolved quite rapidly, and the categorization of 2002 was soon obsolete. In 2008 a new law, No. 10042, was approved. This law introduced a different categorization, one that was similar to that of the European Union. Table 1 summarizes the SME categories, including the criteria for each.

Entities included as a SME are generally considered crucial for a small economy like Albania. The data from the Albanian Institute of Statistics (INSTAT; Business Register in Albania, 2014) show that the contribution of the SMEs in the Gross Domestic Product is higher than 76 per cent and that more than 81 per cent of the workforce is engaged in SME companies. Data from INSTAT (Business Register in Albania, 2014) show that the SME sector is mostly dominated by micro-enterprises, which represent almost 90 per cent of all SMEs.

As such an important sector in the economy, the design and application of an appropriate framework for financial reporting and accounting for SMEs is very important. Sound and reliable financial reporting is considered crucial for the development and growth of companies because it assists management to advance decisions as well as facilitating the acquiring of capital and raising of funds to cover debt and borrowings. This is especially true for the finances of the SME companies, which

\footnotetext{
${ }^{1}$ Rezarta Shkurti, Faculty of Economics, University of Tirana, Tirana, Albania, rezartaperri@feut.edu.al

${ }^{2}$ Brunilda Duraj, Faculty of Economics, University of Tirana, Tirana, Albania, durajbruna@gmail.com
} 
usually either lack assistance from qualified accounting personnel or are not required to be audited. Thus, the International Accounting Standards Board (IASB) introduced a special International Financial Reporting Standards regarding the SMEs, in 2009. The IFRS foundation reported that SMEs accounted for over 95 per cent of all companies worldwide.

Table 1: Structure and categorization of the SMEs in Albania

\begin{tabular}{|l|l|l|l|}
\hline Entity & Number of employees & Annual turnover & Ownership structure \\
\hline Micro-enterprise & $1-9$ employees & $\begin{array}{l}<10 \text { million ALL } \\
(71,000 \text { Euro })\end{array}$ & $\begin{array}{l}100 \text { percent owned by } \\
\text { individuals }\end{array}$ \\
\hline Small business & $10-49$ employees & $\begin{array}{l}<50 \text { million ALL } \\
(357,000 \text { Euro })\end{array}$ & $\begin{array}{l}100 \text { percent owned by } \\
\text { individuals }\end{array}$ \\
\hline $\begin{array}{l}\text { Medium economic } \\
\text { entity }\end{array}$ & $50-249$ employees & $\begin{array}{l}<250 \text { million ALL } \\
(1,785,000 \text { Euro })\end{array}$ & $\begin{array}{l}\text { Less than } 25 \text { percent } \\
\text { could be owned by } \\
\text { entities which are not } \\
\text { classified as SME. }\end{array}$ \\
\hline
\end{tabular}

Source: Law no. 10042 in Albania

In this study, we introduce the characteristics of the Accounting and Financial Reporting Framework for SMEs in Albania and abroad. We start by summarizing the features of the IFRS for SME and, after giving a short introduction about the general situation of financial reporting in Albania, we analyze the why Albania has not adopted the IFRS for SMEs. We revise the NAS for compliance with the IFRS for SMEs, rather than for all company types (the full IFRS). In the last part of the paper, we discuss differences in the treatment of several items in the IFRS for SMEs and in the NAS. We conclude by summarizing the main findings and conclusions.

\section{International Financial Reporting Standards for Small and Medium Enterprises}

In July 2009, the International Accounting Standards Board published the IFRS for SMEs ${ }^{3}$. This standard aimed to simplify the financial reporting for the SMEs by reducing the overall accounting rules, eliminating most of the detailed requirements included in the full IFRS, and avoiding the complex alternative treatments of the full IFRS suggested in certain particular topics. The board took more than five years to develop this standard to its full extension, during which time it considered many comments and remarks by the small and medium companies, which were involved in discussions. Globally, the formal SMEs contribute up to 45 per cent of total employment and up to 33 per cent of national income (GDP) in emerging economies (World Bank, 2015) with a much higher number considered as informal SMEs. Therefore, this particular standard on SMEs financial reporting was of high interest and a practical necessity.

The IFRS for SMEs represents a standalone document organized by theme or topic; it does not follow the same sequence as the full IFRS, nor does it contain cross-referencing. In this context, the IFRS for SMEs is regarded a simplified version of the full IFRS. It is considerably reduced in volume compared with the full IFRS and contains fewer information disclosure requirements than the full set of standards. Compared to the full IFRS, the IFRS for SMEs requires merely a tenth of the information disclosures required under the full IFRS. The main differences between the full IFRS and the IFRS for SME are summarized in Table 2.

Table 2. The main differences between the full IFRS and the IFRS for SMEs

\begin{tabular}{|l|l|}
\hline \multicolumn{1}{|c|}{ Full IFRS } & \multicolumn{1}{c|}{ IFRS for SME } \\
\hline $\begin{array}{l}\text { Standards are published numbered in } \\
\text { consecutive order }\end{array}$ & $\begin{array}{l}\text { The standard is organized according the theme } \\
\text { (topic) }\end{array}$ \\
\hline Almost 3000 pages in total & $\begin{array}{l}\text { Almost 240 pages (about 10 per cent of full } \\
\text { IFRS) }\end{array}$ \\
\hline About 3000 requirements for information & Significantly fewer disclosures are required \\
\hline
\end{tabular}

\footnotetext{
${ }^{3}$ The IFRS for SMEs has been revised in December 2015, but the paper is based on the original IFRS for SMEs.
} 


\begin{tabular}{|l|l|}
\hline disclosures & (roughly a 90 per cent reduction) \\
\hline Is usually updated on a monthly basis & $\begin{array}{l}\text { Revisions to the IFRS for SMEs are not } \\
\text { expected to be made more frequently than once } \\
\text { every three years }\end{array}$ \\
\hline Source: IFRS for SMEs Fact Sheet (2016) & \\
\hline
\end{tabular}

The objective of the IFRS for SMEs is to:

- Increase the comparability of the information for different SMEs across the world;

- Increase the overall trust and reliability in SMEs financial information and accounting;

- Reduce the costs of accounting and financial reporting services on a national basis; and

- Provide a uniform financial information platform for expanding businesses that are expected to require access to public capital markets.

In general, companies that do not represent any public interest and that publish financial statements of general purposes for third parties, i.e., external users, are permitted to use the IFRS for SMEs. Specifically, in each jurisdiction, the domestic legislative authorities decide which economic entity will be required to report under IFRS for SMEs. The only limitation imposed by the IASB is that the listed companies and the financial institutions, in any country, are not permitted to report under the IFRS for SMEs. Currently, 78 of the 140 jurisdictions worldwide require (or permit) the use of IFRS for SMEs (IFRS for SMEs Fact Sheet, 2016). There are 70 jurisdictions of the 78 in total that have adopted the IFRS for SMEs without any modification to the Standard.

\section{Financial Reporting Framework in Albania}

Since January 2008, Albania has applied a set of national Accounting Standards that were prepared in compliance with the IFRS. The introduction of the NAS came as a necessity to improve the financial reporting environment in Albania, because prior to these standards, the situation involved a General Financial Accounting Plan (GFAP), which was inherited from the centrally planned economic period and could not reflect all the dynamics of business transactions in the market economy implemented in Albania after the 1990s. The NAS were prepared, mostly based on IFRS rules and provisions. This basis was illogical because the IFRS are mostly specific to large public companies, whereas the companies in Albania, were mainly SMEs, as previously mentioned. Due to this contradiction, the NAS were revised in 2014 with the new version effective since January 1, 2016. The revised NAS comply (although not fully) with the IFRS for SMEs, but are not in compliance with the full IFRS.

Currently, the companies in Albania are classified into three tiers4 regarding the financial reporting framework for which they should comply. These tiers are as follows:

- Tier 1 includes economic entities that are required to apply the full IFRS. This group consists of listed companies and other public interest entities (banks and financial institutions, insurance and reinsurance companies, and securities and investments funds) regardless of whether they are listed on a public stock market. Other companies required to report under the full IFRS are the large (and unlisted) companies that have met the following two criteria within the last two financial years: (1) annual revenues higher than 1,250,000,000 Albanian lek (approximately 9,000,000 Euro); and (2) average annual number of employees greater than 100 persons.

- Tier 2 includes the economic entities that are required to apply the 14 revised National Accounting Standards. Usually, this group includes the small and medium enterprises that operate in Albania.

- Tier 3 includes the economic entities that are required to report their accounting and financial information according to Standard 15 of the NAS. All micro-enterprises are usually included in this last group. There is an Albanian Decree of Council of Ministers, No. 969 (DCM, 2009),

\footnotetext{
${ }^{4}$ Regarding the financial reporting of the public sector (the government agencies) and the non-profit organizations, there are also other standards and regulations, not shown in this paper, because we try to focus mainly on the private sector companies, and especially focusing on the small and medium enterprises.
} 
which requires the micro-sized entities to report under a special regime of accounting and financial rules.

There are several studies (Dhamo, Miti, \& Lera, 2008; Ujkani \& Zyka, 2010; Këri \& Spahiu, 2011; Shkurti \& Gjoni, 2010) revealing that, although the first time (and subsequent) application of the NAS was difficult; in general, it could still be regarded as a successful process. The main difficulties of this process involved the following: understanding the new terms and concepts of the standards; focusing the periodic reporting more towards the fiscal regulations than accounting rules; the lack of professional capacities for correct standard application; the lack of active commodities and financial markets; and economic development stages.

On January 1, 2009, the 15th National Accounting Standard became effective in Albania. This new standard, "On accounting and financial reporting principles of the micro sized entities", was designed to be fully compatible with the recommendations of the United Nations (UN) on accounting regulation of micro-enterprises, as well as that of the IFRS for SMEs. Several years later, in June 2013, the IASB, issued a "Guide for Micro-Sized Entities Applying the IFRS for SMEs". This document has no legal binding in Albania, but since 2014, it has influenced the revision of the NAS.

As previously mentioned in this paper, the current set of NAS was designed to be completely aligned with the full IFRS. However, the Albanian economy is mostly oriented towards small and medium enterprises and when the new IFRS for SMEs was published, the National Accounting Committee (NAC) of Albania undertook thorough discussions as to whether Albania should endorse the new IFRS, or continue with the NAS, possibly revising them in light of the IFRS for SMEs. After studying the new IFRS for SMEs, it appeared that between the IFRS for SMEs and the Albanian NAS there were several critical distinctions as well as topics that were not mentioned in the Albanian NAS. Therefore, the NAC was faced with a decision to either endorse the IFRS for SME or revise the NAS in Albania. The decision to revise the existing NAS was preceded by a series of discussions, workshops, and debates.

Even though the IFRS for SMEs was endorsed by 78 countries (IFRS for SMEs Fact Sheet, 2016), Albania decided against it because the EU countries were mostly not in favor of it and preferred to simplify the overall financial reporting rules with application of the 4th and 7th Directives. As a country which aspires to become part of the European "family", Albania decided that its focus should comply with the Directives rather than with the IFRS for SMEs. Another reason why the NAC argued that revising the existing NAS was a better alternative than implementing the IFRS for SMEs, was that the accountants in Albania were already accustomed to the NAS, because they had been applying and using these standards for over five years, and therefore it would be easier for them to deal with the revised standards rather than a newly introduced IFRS.

\section{Comparison between IFRS for SMEs and Revised NAS in Albania}

Notably, the IFRS for SMEs in itself represents several differences to the full IFRS regime. However, the process of revising the NAS in Albania was aimed at minimizing, the differences between the two platforms, i.e., the financial reporting platform for the SMEs (including the IFRS for SMEs), and that for the revised NAS in Albania. Nevertheless, some differences still remain, as presented and discussed below, because they assist with understanding the degree of variation in financial information between the two financial reporting platforms. Especially, when comparing financial statements between two different accounting frameworks, one should bear in mind the following differences:

1. The presentation of financial information in the financial statements

- IFRS for SMEs: allow the combination of the Statement of Comprehensive Income with the Statement of Changes in Capital when changes in capital result from income or loss, dividend distribution, correcting errors of previous period, or changes in accounting policies, or a combination of these (paragraphs 6.4, 6.5).

- The Albanian NAS: do not allow the combination of the above mentioned statements. The NAS No 2 specifically states that the four main financial statements should be presented 
separately and furthermore, it specifies the minimum elements that each of the statements should include.

2. The borrowing costs

- IFRS for SMEs: contain the paragraph 25.2, which treats the borrowing costs as period expenses that should be recognized in the income statement of the reporting period. In contrast, the full IFRS rules require that the borrowing cost be capitalized with asset cost. It is argued in the IFRS for SMEs that because small and medium enterprises have a cost-benefit causal relation that cannot be reliably measured the borrowing costs cannot be capitalized wholly with the asset cost.

- Albanian NAS: contain the revised NAS No 5 (article 14), which treats the borrowing costs as period expenses, the same as that of the IFRS for SMEs.

3. Research and development costs

- IFRS for SMEs: The full IFRS standards call for expending the pure scientific research costs and to capitalize and amortize applied research costs over a span of years, while in the IFRS for SMEs, the treatment of research \& development costs is completely different. This standard (articles 18.14, 18.15, \& 18.16) requires the company to recognize all research expenses within the period in which they are incurred.

- Albanian NAS: The revised NAS No 5 (article 59), in alignment with IFRS for SMEs, requires the research \& development costs to be recognized as period expenses as incurred, unless they form part of the cost of another asset that fulfills the criteria set in this standard.

4. Financial instruments

- IFRS for SMEs: Regarding the financial instruments, the SMEs can choose either to apply the full IFRS rules or to combine the requirements of the IAS 39 with those of IFRS for SMEs.

- Albanian NAS: The revised NAS have excluded the fair value model for measurement and valuation of the financial instruments. Therefore, the model of first time recognition and the subsequent measurement of the financial instruments is the amortized cost model (NAS No 3; articles $11 \& 15)$.

5. Intangible assets and the goodwill

- IFRS for SMEs: No difference is ascribed between the long-term intangible assets with limited useful life and those with unlimited life. All non-financial long-term assets are subject to amortization and to be tested for any possible depreciation if any indication of depreciation arises.

- Albanian NAS: The revised NAS treat the intangible assets in the same manner as the IFRS for SMEs. According to article 70 in IFRS for SMEs, all intangible assets, including goodwill, are considered as assets that should be amortized over a limited useful life. In cases where the small or medium enterprise is not able to define a useful life for the intangible asset, it will be presumed to be ten years.

6. Business combination

- IFRS for SMEs: This standard allows the use of either the method of interest joining or the method of purchasing (which in itself has two different allowed approaches).

- Albanian NAS: These accounting standards allow a company during purchase transactions to use the method of net capital, in compliance with the treatment required under the full IFRS.

\section{Conclusion}

In this study, we focused on the area of accounting and financial reporting in Albania. It is critical that companies in this small country present their information in a reliable manner and in a way that allows potential investors to distribute funds more efficiently. Most companies are small and medium 
enterprises in Albania and therefore, in developing accounting rules, authorities have tried to consider the specifics of this sector.

Prior to 2008, Albania upheld the General Financial Accounting Plan, which was a particular platform for financial reporting that was inherited from the time of a centrally planned economy. As it was not appropriate to continue with such a platform, the National Accounting Council in Albania (NACA) prepared a set of 14 standards of accounting. Initially, these standards were prepared in accordance with the full IFRS framework, and it was considered a tremendous change and adaptation of the financial reporting environment in Albania.

However, the IASB issued a specific standard for reporting by SMEs. From research, it was concluded that the majority of the economic entities in Albania were small and medium enterprises, and thus, the NACA decided to revise the NAS to comply with the IFRS for SMEs. The NACA decided not to endorse the IFRS for SMEs because the EU countries in general were not in favor of this standard, even though more than 80 countries had adopted it worldwide; Albania tended towards complying with the European Commission Directives because it aspired to join the EU; and because several overwhelming changes would exist for the accountants in Albania to completely change the financial reporting platform only five years after it had initially been introduced (and grasped with difficulties by these professionals).

Even though the NACA tried to avoid discrepancies between the IFRS for SMEs and the Albanian NAS, there were still differences, such as that relating to the presentation of financial information in the financial statements; the treatment of financial instruments; and the business combinations. Nonetheless, it is important to view the manner in which both platforms may be revised in future years.

\section{References}

Arowomole, K. A. (2000). Modern Business Management (Theory and Practice), (1st Edition). Sango-Ota, Ogun State: AdeOluyinka Commercial Press (Chapter 132).

Business Register in Albania (2014). A publication of the Institute of Statistics in Albania, INSTAT. Retrieved March 08, 2016, from www.instat.gov.al/media/298854/registri_ndermarrjeve_2014.pdf

Darren, L. \& Conrad, L. (2009). Entrepreneurship and Small Business management in the Hospitality Industry. Jordan Hill, UK: Elsevier Linacre House.

Decree of Council of Ministers (DCM) in Albania, no 969 (2009). "The criteria for accounting and financial statements from micro entities".

Dhamo, S., Miti, M., \& Lera, N. (2008). "Accounting standards and tax reporting in Albania-challenges and problems", International Conference "Economic \& Social-Challenges and Problems, 2008"; Volume 3, pages 57-79.

IFRS for SMEs Fact Sheet (2016). IFRS Foundation publication. Retrieved March 08, 2016 from http://www.ifrs.org/IFRSfor-SMEs/Pages/IFRS-for-SMEs.aspx

Këri, L., \& Spahiu, A. (2011). "Implementing IFRS for SME- a challenge for Albania"; International Conference "Economic \& Social-Challenges 2011, Globalization and Sustainable Growth", University of Tirana, Faculty of Economics, December 2011, Volume II, pages 35 - 47.

Shkurti, R. \& Gjoni, B. (2010). Development of the Accounting Profession in Albania in the New Era of Market Economy. Studies in Business and Economics Journal, Volume 5, Issue 3, December 2010, pages 247-258.

SMEs Finance, World Bank publication (2015). Retrieved March 08, 2016, from http://www.worldbank.org/en/topic/financialsector/brief/smes-finance

Ujkani, M. \& Zyka, E. (2010). International Financial Reporting Standards for Small and Medium Sizes Entities and its implementation, International Conference "Economic \& Social Challenges and problems 2010-At the time of global crisis and integration" 11-12 December 2010, Volume I, pages 109-199. 